\title{
Analysis of dermatological diseases of Syrian asylum seekers
}

Suriyeli sığınmacıların dermatolojik hastalıklarının analizi

\section{Fidan Bener}

Darıca Farabi Training and Research Hospital, Clinic of Dermatology, Kocaeli, Turkey

\begin{abstract}
Background and Design: The aim of this study was to determine the dermatological problems and demographic characteristics of the Syrian asylum seekers admitting to our outpatient clinic.

Materials and Methods: In this study, the data of the Syrian patients who were examined at the clinic of dermatology outpatient between 2014-2018 were analyzed retrospectively.

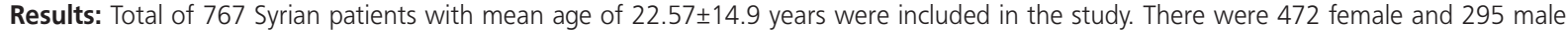
patients. Infections and infestations were the most common disease groups observed in both female and male patients across all cases. Scabies was the most common disease in all cases and men. However, in women the most common disease was acne vulgaris. Evaluation of diagnoses based on age groups and years showed that the most common disease group was infection and infestations in 0-18, 19-40, 41-60 age groups and in all years, and dermatitis and eczema in patients over the age of 60. The most common disease was scabies for 0-18 and 41-60 age groups, acne vulgaris in 19-40 age group and pruritus in over-60 age group; scabies was the most common disease in 2014 and 2015, and acne vulgaris in 2016 and 2017. Evaluation based on years showed that the prevalence of infectious dermatological disease was significantly decreased whereas the prevalence of diseases other than infectious dermatological diseases were significantly increased $(p<0.05)$.

Conclusion: In our study, it was determined that the most common disease groups were infection and infestations and the most common disease was scabies. These results reveal that asylum seekers are under the threat of infectious dermatological diseases. However, it is also observed that this risk is significantly reduced over the time they have been living in our country.
\end{abstract}

Keywords: Syrian asylum seekers, dermatological diagnoses, demographic features

Öz

Amaç: Polikliniğimize başvuran Suriyeli sığınmacıların dermatolojik problemleri ve demografik özelliklerinin belirlenmesi amaçlanmıştır. Gereç ve Yöntem: Bu çalışmada 2014-2018 yılları arasında dermatoloji polikliniğinde muayenesi yapılmıs Suriye uyruklu hastaların verileri retrospektif olarak incelenmiştir.

Bulgular: Çalışmaya kabul edilen 767 Suriyeli hastanın yaş ortalaması 22,57ะ14,9 idi. Olguların 472'si kadın, 295'i erkek idi. Tüm olgularda, kadın ve erkeklerde en sık görülen hastalık grubu enfeksiyon ve enfestasyonlar idi. En sık görülen hastalık ise tüm olgularda ve erkeklerde skabiyez, kadınlarda ise akne vulgaris idi. Tanılar yaș gruplarına ve yıllara göre incelendiğinde 0-18, 19-40, 41-60 yaş gruplarında ve tüm yıllarda en sık görülen hastalık grubu enfeksiyon ve enfestasyonlar, 60 yaş üstünde ise dermatit ve egzema idi. En sık görülen hastalık ise 0-18, 41-60 aralı̆ında skabiyez, 19-40 yaş aralığında akne vulgaris, 60 yaş üzerinde pruritus; 2014 ve 2015 yıllarında skabiyez ve 2016 ve 2017 yıllarında ise akne vulgaris idi. Yıllara göre incelendiğinde bulaşııı dermatolojik hastalık görülme oranının anlamlı olarak azaldığı, bulaşıcı dermatolojik hastalıkların dışındaki hastalıkların ise anlamlı olarak arttığı tespit edildi $(p<0,05)$.

Sonuç: Çalı̧mamızda en sık görülen hastalık grubunun enfeksiyon ve enfestasyonlar olduğu, en sık görülen hastalı̆̆ın ise skabiyez olduğu belirlenmiştir. Bu sonuçlar sığınmacıların bulaşıcı dermatolojik hastalıklar açııından tehdit altında olduğunu göstermektedir. Fakat ülkemizde yaşadıkları süre içerisinde bu riskin anlamlı olarak azalmaya başladığı görülmüştür.

Anahtar Kelimeler: Suriyeli sığınmacılar, dermatolojik tanılar, demografik özellikler

Address for Correspondence/Yazıșma Adresi: Fidan Bener MD, Darıca Farabi Training and Research Hospital, Clinic of Dermatology, Kocaeli, Turkey Phone: +90 5057186633 E-mail: drfidanyg@yahoo.com Received/Geliş Tarihi: 20.09.2019 Accepted/Kabul Tarihi: 21.04.2020 ORCID: orcid.org/0000-0002-4390-7070

CCopyright 2020 by Turkish Society of Dermatology and Venereology

Turkderm - Turkish Archives of Dermatology and Venereology published by Galenos Yayinevi. 


\section{Introduction}

After the unrest in Syria escalated to civil war in 2011, approximately 5 million Syrians were forced to emigrate ${ }^{1}$. According to the data of Ministry for Internal Affairs Directorate of Immigration Management, there are 3,657,694 Syrians under temporary protection scheme and $58,009(3.04 \%)$ of these reside within Kocaeli province [Republic of Turkey Ministry of Interior Directorate General of Migration Management, Statistics: Up-to-date statistics; Temporary protection (updated 2019 Aug 28). Available from: https://www.goc.gov.tr/ gecici-koruma5638]. Significant number of Syrian asylum seekers lives in Darıca, where our hospital is at, and nearby districts. As Syrian asylum seekers gained a permanent residency status, they have led to many economical, socio-cultural and health related impacts on local people ${ }^{2}$. Major changes have occurred in the variety and frequency of dermatological diseases in places that are highly populated with asylum seekers ${ }^{3}$.

There are very few number of studies conducted on the dermatological diseases observed in Syrian asylum seekers living in our country and their epidemiological effects. In an attempt to provide insight, we aimed to determine the variety of dermatological diseases and the demographic features of the patients by retrospectively analyzing the data of Syrian patients.

\section{Materials and Methods}

The files of the Syrian patients who were examined the Dermatology Policlinic of Darıca Farabi Research and Training Hospital between 1 January 2014 and 1 January 2018 were scanned retrospectively. The study was approved by the University of Health Sciences Turkey, Hamidiye Non-invasive Research Ethics Committee (approval number: 46418926, date: 30.11 .2018 ). All these procedures were performed in accordance with the principles of the Declaration of Helsinki.

\section{Study design}

Medical files of Syrians patients, who had undergone examination between 1 January 2014 and 1 January 2018, were retrospectively analyzed. Age, gender and dermatological findings of the patients were determined from the automation system of the hospital. For each patient within the same year; examinations performed with the same diagnosis as the control examinations were considered as one, and admissions made in the same examination or admissions with different diagnosis are considered as additional diagnoses. Diagnoses were classified according to International Classification of Diseases-10 (ICD10). Detected diseases were categorized as infections and infestations, disorders of skin appendages, dermatitis and eczema, papulosquamous disorders, urticaria and erythema, benign neoplasms of skin, radiationrelated disorders of the skin and subcutaneous tissue, bullous disorders and other disorders of the skin and subcutaneous tissue in 9 groups and analyzed. Prevalence of the diseases were determined. The most common diseases were analyzed based on age groups (0-18, 19-40, 51-60 and over 60) and admission year.

\section{Statistical Analysis}

Statistical analyses were performed with SPSS 22 (SPSS Inc., Chicago, Illinois, USA) program. Descriptive statistics were presented by frequencies, percentages, mean \pm standard deviation values.
Comparisons between groups of independent samples were assessed with a Student's t-test. Categorical data were compared by Pearson's chi-square test. $P<0.05$ was considered statistically significant.

\section{Results}

Among 73,137 outpatient examinations performed between 1 January 2014 and 1 January 2018 in dermatology clinic 767 (1.05\%) of them belonged to Syrian patients. Mean age of the cases was $22.57 \pm 14.9$ years (minimum: 0, maximum: 79). There were 472 (61.5\%) female and 295 (38.5\%) male patients. Mean age of female and male patients were $23.87 \pm 15.06$ (minimum: 0 , maximum: 79 ) years and 21.94 \pm 14.69 (minimum: 0, maximum: 73), respectively. There was no statistically significant difference in terms of age distribution based on gender between these groups ( $p>0.05)$. Patients were analyzed according to their admission year and age groups (0-18, 19-40, 41-60 and over 60) (Table 1). There were 316 patients in 0-18 age group (mean age: 9.3 \pm 5.8 ). Among these 316 patients, there were 190 girls and 126 boys, and their mean ages were $9.8 \pm 5.7$ years and $8.4 \pm 5.7$ respectively. There was a statistically significant difference in terms of age distribution based on gender between these groups $(p<0.05)$. Highest number of admissions was from the 19-40 age group (47.3\%) and in 2017 (49\%). Patients between 0-40 years of age comprised the $88.5 \%$ of all cases.

There were total of 879 diagnoses; 99 of them were second diagnosis and 13 were third diagnosis. It was determined that female patients received 549 diagnoses, male patients 330 and child patients received 355 diagnoses. Prevalence of diseases that are categorized under nine groups according to ICD-10 is presented in Table 2, 3. The most common disease groups in all cases were infections and infestations (38.5\%), disorders of skin appendages (22.5\%) and dermatitis and eczema $(21 \%)$, and the most common diseases were scabies (14.8\%), acne vulgaris (11.7\%) and contact dermatitis (9.6\%). The most common disease groups in female patients were infections and infestations (31.1\%), disorders of skin appendages (25.5\%) and dermatitis and eczema (22.8\%), and the most common diseases were acne vulgaris (14.2\%), scabies (13.1\%) and contact dermatitis (12\%). The most common disease groups in male patients were infections and

\begin{tabular}{|c|c|c|c|c|c|c|}
\hline \multirow[t]{2}{*}{ Age } & \multicolumn{2}{|c|}{ Patient } & \multicolumn{2}{|c|}{ Female } & \multicolumn{2}{|c|}{ Male } \\
\hline & $n$ & $\%$ & $\mathrm{n}$ & $\%$ & $\mathrm{n}$ & $\%$ \\
\hline $0-18$ & 316 & 41.2 & 190 & 24.8 & 126 & 16.4 \\
\hline $19-40$ & 363 & 47.3 & 227 & 29.6 & 136 & 17.7 \\
\hline $41-60$ & 72 & 9.4 & 45 & 5.9 & 27 & 3.5 \\
\hline $60>$ & 16 & 2.1 & 10 & 1.3 & 6 & 0.8 \\
\hline \multirow[t]{2}{*}{ Year } & \multicolumn{2}{|c|}{ Patient } & \multicolumn{2}{|c|}{ Female } & \multicolumn{2}{|c|}{ Male } \\
\hline & $n$ & $\%$ & $\mathrm{n}$ & $\%$ & $\mathbf{n}$ & $\%$ \\
\hline 2014 & 87 & 11.3 & 49 & 6.4 & 38 & 4.9 \\
\hline 2015 & 112 & 14.6 & 69 & 9 & 43 & 5.6 \\
\hline 2016 & 192 & 25 & 117 & 15.3 & 75 & 9.8 \\
\hline 2017 & 376 & 49 & 237 & 30.9 & 139 & 18.1 \\
\hline
\end{tabular}


Table 2. Prevalence of disease groups

\begin{tabular}{|l|l|l|l|}
\hline Disease groups & $\begin{array}{l}\text { Number of } \\
\text { diagnoses }\end{array}$ & $\%$ \\
\hline $\begin{array}{l}\text { Infections and } \\
\text { infestations }\end{array}$ & Parasitic diseases & 154 & 17.5 \\
\cline { 2 - 4 } & Mycoses & 83 & 9.4 \\
\cline { 2 - 4 } & Viral diseases & 64 & 7.3 \\
\cline { 2 - 4 } & Bacterial diseases & 37 & 4.2 \\
\hline Disorders of skin appendages & 198 & 22.5 \\
\hline Dermatitis and eczema & 185 & 21.1 \\
\hline $\begin{array}{l}\text { Other disorders of the skin and subcutaneous } \\
\text { tissue }\end{array}$ & 70 & 8 \\
\hline Papulosquamous disorders & 29 & 3.3 \\
\hline Urticaria and erythema & 19 & 2.2 \\
\hline Benign neoplasms of skin & 9 & 1 \\
\hline $\begin{array}{l}\text { Radiation-related disorders of the skin and } \\
\text { subcutaneous tissue }\end{array}$ & 5 & 0.6 \\
\hline Bullous disorders & 1 & 0.1 \\
\hline
\end{tabular}

infestations (50.6\%), dermatitis and eczema (18.2\%) and disorders of skin appendages (17.6\%), and the most common diseases were scabies (17.6\%), acne vulgaris (7.6\%) and viral warts (5.8\%). There was a statistically significant difference between the three most common disease groups in female and male patients $(p<0.05)$.

Diagnoses were also reviewed based on admission year and age groups (Table 4). In children, most common disease group was infections and infestations (43.1\%) and most common disease was scabies (16.6\%). In 19-40 and 41-60 age groups, most common disease group was infections and infestations ( $25.7 \%$ and $40 \%$, respectively), and most common diseases were acne vulgaris (14.9\%) and scabies (9.4\%), respectively. Most common disease group over 60 age group was dermatitis and eczema (40.9\%), and most common disease was pruritus $(22.7 \%)$. Acne vulgaris was found to be the most common disease in 10-19 (19.1\%) and 19-30 (23.3\%) age groups and was more apparent in female patients. Analysis of diagnoses based on year showed that most common disease group was infections and infestations and scabies was the most diagnosed disease in 2014 and 2015 and acne vulgaris in 2016 and 2017. Prevalence of infectious dermatological disease was 52\%, 52.6\%, 45.3\%, 37.5\% and shown to be decreasing gradually over the years. On the other hand, prevalence of non-infectious diseases exhibited an increasing trend with $48.27 \%$, $48.21 \%, 72.91 \%$ and $77.39 \%$ (Figure 1). Comparison of 2014 and 2017 data revealed statistically significant difference in terms of the changes observed between these two groups $(p<0.05)$.

\section{Discussion}

Asylum seekers form the most vulnerable and exposed group in terms of health due to many factors they encounter during their course. They face more health threats as they had to start a new life in a socioeconomically disadvantaged position, to work and live under difficult conditions most of the time ${ }^{4}$. According to Republic of Turkey Ministry of Interior Disaster and Emergency Management Presidency (AFAD) 2014 report, prevalence of dermatological disease in Syrian asylum seekers living in tent cities was 23\% (AFAD, 2014. Suriye'den

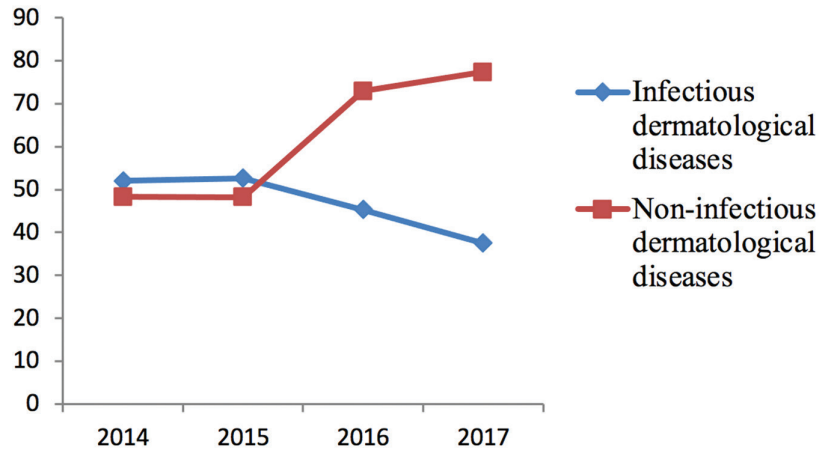

Figure 1. Course of infectious and non-infectious dermatological diseases throughout the years

Türkiye'ye Nüfus Hareketleri Kardeş Topraklarındaki Misafirlik. Available from: https://www.afad.gov.tr/upload/Node/3931/xfiles/ webformatisuriyedenturkiyeyenufushareketleri.pdf). In another primary health care study conducted, it was reported that $8.6 \%$ of admissions involved dermatological problems 5 . In a study conducted in Brussels with 3907 asylum seekers, 20\% being Syrian patients, prevalence of dermatological diseases was found to be $8.6 \%{ }^{6}$. Authors of a study in Lebanon reported that infectious dermatological diseases were detected in $47 \%$ of 90,000 displaced Syrian patients ${ }^{7}$.

In our study, dermatological diseases and demographic features of Syrian asylum seekers were retrospectively reviewed. The only study on this topic in our country was conducted by Inci et al. ${ }^{3}$ on 326 Syrian cases. In our study, mean age of 767 patients was $22.57 \pm 14.92$. There were 472 female and 295 male patients, and number of female patients was significantly higher. However, female Syrian asylum seekers (49.2\%) are reported to be less than their male compatriots (50.8\%) (AFAD, 2018. Türkiye'deki Suriyelilerin demografik görünümü, yaşam koşulları ve gelecek beklentilerine yönelik saha araştırması. Available from: https:// www.afad.gov.tr/upload/Node/24384/xfiles/17a-Turkiye_deki_ Suriyelilerin_Demografik_Gorunumu_Yasam_Kosullari_ve_Gelecek_ Beklentilerine_Yonelik_Saha_Arastirmasi_2017.pdf). Highest number of hospital admission had taken place in 2017 and it was determined that most of the cases for both genders were from 18-40 (47.3\%) age group and patients between $0-40$ years of age comprised $88.5 \%$ of all patients. These demographic findings we obtained have similarities with that of those in the study conducted by Inci et $\mathrm{al}^{3}$. The fact that the Syrian population immigrated to our country was young has been associated with the young population of Syria and elder Syrians not leaving the country due to senility and disability (AFAD, 2014. Suriye'den Türkiye'ye Nüfus Hareketleri Kardeş Topraklarındaki Misafirlik. Available from: https://www.afad.gov.tr/upload/Node/3931/xfiles/ webformatisuriyedenturkiyeyenufushareketleri.pdf).

In our study, it was determined that the most common disease group was infections and infestations (38.5\%) and the most common disease was scabies (14.8\%). Population affected by the war in Syria and people living in camps established in neighboring countries are under risk for scabies $^{8}$. Red flag report has been published about scabies and lice infestations in the population affected by the war in Syria. According to the report, 7,600 scabies cases were recorded in Syria between 2012 and 2015 and $50 \%$ of the population in Aleppo was affected by scabies epidemic (World Health Organization, January, 2015. Syrian Arap republic stuation reports: Regional health situation report. Available 


\section{Table 3. Prevalence of dermatological diseases based on gender}

Groups

Infectionsand

infestations

Disorders of skin appendages

Urticaria and erythema

Bullous disorders

\section{Subgroups}

Parasitic diseases

Mycoses

Viral diseases

Bacterial diseases

Scabies

Leishmaniasis

Insect bite

Pediculosis capitis

Tinea pedis

Onychomycosis

Pityriasis versicolor

Tinea capitis

Tinea cruris

Tinea corporis

Candidiasis

Tinea manum

Viral warts

Varicella

Herpes virus infections

Molluscum contagiosum

Varicella zoster

Genital warts

Hand, foot and mouth disease

Impetigo

Folliculitis

Cellulitis

Furunculosis

Acne vulgaris

Telogen effluvium

Alopecia areata

Epidermal cyst, milium

Hirsutism

Keratosis pilaris

Androgenetic alopecia

Premature hair graying

Acne rosacea

Miliaria rubra

Folliculitis decalvans

Acne keloidalis

Hyperhidrosis

Urticaria, dermographism

Erythema nodosum

Erythema annulare centrifugum

Pemphigus vulgaris

\begin{tabular}{|c|c|c|}
\hline $\begin{array}{l}\text { Total number } \\
\text { of diagnoses }\end{array}$ & Female & Male \\
\hline 130 & 72 & 58 \\
\hline 13 & 9 & 4 \\
\hline 6 & 3 & 3 \\
\hline 5 & 4 & 1 \\
\hline 25 & 9 & 16 \\
\hline 17 & 6 & 11 \\
\hline 13 & 8 & 5 \\
\hline 9 & 2 & 7 \\
\hline 8 & - & 8 \\
\hline 7 & 3 & 4 \\
\hline 2 & 1 & 1 \\
\hline 2 & 1 & 1 \\
\hline 32 & 13 & 19 \\
\hline 10 & 4 & 6 \\
\hline 8 & 4 & 4 \\
\hline 6 & 4 & 2 \\
\hline 5 & 4 & 1 \\
\hline 2 & 1 & 1 \\
\hline 1 & 1 & - \\
\hline 13 & 8 & 5 \\
\hline 18 & 11 & 7 \\
\hline 3 & 1 & 2 \\
\hline 3 & 2 & 1 \\
\hline 103 & 78 & 25 \\
\hline 44 & 42 & 2 \\
\hline 18 & 5 & 13 \\
\hline 7 & 3 & 4 \\
\hline 5 & 5 & - \\
\hline 5 & 3 & 2 \\
\hline 4 & 1 & 3 \\
\hline 3 & - & 3 \\
\hline 3 & 2 & 1 \\
\hline 3 & 1 & 2 \\
\hline 1 & - & 1 \\
\hline 1 & - & 1 \\
\hline 1 & - & 1 \\
\hline 15 & 7 & 8 \\
\hline 3 & 3 & - \\
\hline 1 & 1 & - \\
\hline 1 & 1 & - \\
\hline
\end{tabular}




\begin{tabular}{|c|c|c|c|c|}
\hline Groups & Subgroups & $\begin{array}{l}\text { Total number } \\
\text { of diagnoses }\end{array}$ & Female & Male \\
\hline \multirow{12}{*}{ Dermatitis and eczema } & Contact dermatitis & 84 & 66 & 18 \\
\hline & Generalized pruritus & 37 & 27 & 10 \\
\hline & Seborrheic dermatitis & 35 & 21 & 14 \\
\hline & Intertrigo & 11 & 4 & 7 \\
\hline & Prurigo & 4 & 3 & 1 \\
\hline & Diaper dermatitis & 4 & 1 & 3 \\
\hline & Atopic dermatitis & 3 & - & 3 \\
\hline & Pityriasis alba & 2 & - & 2 \\
\hline & Nipple eczema & 2 & 2 & - \\
\hline & Prurigo nodularis & 1 & 1 & - \\
\hline & Dyshidrosis & 1 & - & 1 \\
\hline & Lichen simplex chronicus & 1 & - & 1 \\
\hline \multirow{13}{*}{ Other disorders of the skin and subcutaneous tissue } & Xerosis cutis & 19 & 14 & 5 \\
\hline & Clavus-callus & 12 & 7 & 5 \\
\hline & Vitiligo & 9 & 7 & 2 \\
\hline & Chloasma & 9 & 9 & - \\
\hline & Pernio & 6 & 2 & 4 \\
\hline & Keloid, scar, striae & 4 & 3 & 1 \\
\hline & Macular amyloidosis & 3 & 3 & - \\
\hline & Freckles & 2 & 2 & - \\
\hline & Palmoplantar keratoderma & 1 & 1 & - \\
\hline & Xanthelasma of eyelid & 2 & 2 & - \\
\hline & Aphthous stomatitis & 1 & - & 1 \\
\hline & Ecchymosis & 1 & 1 & - \\
\hline & Sweet syndrome & 1 & 1 & - \\
\hline \multirow{3}{*}{ Papulosquamous disorders } & Psoriasis & 21 & 11 & 10 \\
\hline & Pityriasis rosea & 5 & 4 & 1 \\
\hline & Lichen planus & 3 & 3 & - \\
\hline \multirow{3}{*}{ Benign neoplasms of skin } & Nevus & 6 & 4 & 2 \\
\hline & Other benign neoplasms & 2 & 1 & 1 \\
\hline & Acrochordon & 1 & 1 & - \\
\hline \multirow{4}{*}{ Radiation-related disorders of the skin and subcutaneous tissue } & Actinic keratosis & 2 & - & 2 \\
\hline & Sunburn & 1 & - & 1 \\
\hline & Fotocontact dermatitis & 1 & 1 & - \\
\hline & Erythema ab igne & 1 & - & 1 \\
\hline
\end{tabular}

from: http://www.who.int/hac/crises/syr/sitreps/en/). It was reported that, between 2009 and 2013, 19.1\% of the children living in camps where more than $92 \%$ of its residents were Syrian and Iraqi asylum seekers had soft tissue infections such as streptococcal infection, scabies and lice 9 . In a study conducted in Germany, scabies were detected in 16 of 52 patients, $40 \%$ of whom were Syrian asylum seekers ${ }^{10}$. Infectious diseases that were previously seen only in a certain area can be moved to new places through immigrants and can increase the incidence of the disease ${ }^{11}$. Therefore, we believe that there is a potential risk for scabies epidemic due to the contact between the affected patients and the local people. Epidemiological studies including local people can be helpful for community health.

In the study conducted by inci et al. ${ }^{3}$, although dermatological infectious diseases were the most common disease group, scabies was detected in only two cases. In addition, cutaneous leishmaniasis (CL) was found to be the most diagnosed disease ${ }^{3}$. CL is highly common in Syria. In a study in Aleppo, it was reported that 17,709 cases in 2007 increased to 58,156 in $2011^{12}$. The disease has a significant extent especially in our Southeastern Anatolian provinces due to the increased immigration from Syria to our country. In a retrospective study conducted by Korkmaz et al. ${ }^{13}$ in Gaziantep after migration wave, there were 67 Turks and 568 Syrians among $635 \mathrm{CL}$ patients. There were 13 (1.6\%) cases diagnosed with $\mathrm{CL}$ in our study. The reason for having lesser $\mathrm{CL}$ cases than the study by Inci et al. ${ }^{3}$ may be caused by the late arrival of asylum seekers to our region and them having received treatment in the camps during that time or that they may have come from regions where $\mathrm{CL}$ is less common.

In our study, different from inci et al. ${ }^{3}$, more superficial fungal diseases (9.4\%) were detected. Among viral diseases, which significantly affect children, wart was most frequently diagnosed (3.6\%). In comparison to other infectious diseases, prevalence of bacterial diseases was very low (4.3\%). 
Table 4. Common disease groups and diseases based on age groups and years

\begin{tabular}{|c|c|c|c|c|c|}
\hline Age & $\begin{array}{l}\text { Number of } \\
\text { diagnoses }\end{array}$ & The most common groups & $\begin{array}{l}\text { Percentage within group } \\
(\%)\end{array}$ & $\begin{array}{l}\text { The most common } \\
\text { diseases }\end{array}$ & $\begin{array}{l}\text { Percentage within group } \\
(\%)\end{array}$ \\
\hline \multirow{3}{*}{$0-18 s$} & \multirow{3}{*}{355} & ॥ & 43.1 & Scabies & 16.6 \\
\hline & & $\mathrm{DE}$ & 23.9 & Acne vulgaris & 10.7 \\
\hline & & DSA & 22.5 & Contact dermatitis & 9 \\
\hline \multirow[t]{3}{*}{$19-40$} & \multirow[t]{3}{*}{417} & II & 25.7 & Acne vulgaris & 14.9 \\
\hline & & $\mathrm{DE}$ & 24 & Scabies & 14.2 \\
\hline & & DSA & 21.6 & Contact dermatitis & 11.5 \\
\hline \multirow[t]{3}{*}{$41-60$} & \multirow[t]{3}{*}{85} & ॥ & 40 & Scabies & 9.4 \\
\hline & & $\mathrm{DE}$ & 22.4 & Tinea pedis & 8.2 \\
\hline & & ODSST & 11.8 & Contact dermatitis & 8.2 \\
\hline \multirow[t]{3}{*}{$60>$} & \multirow[t]{3}{*}{22} & $\mathrm{DE}$ & 40.9 & Pruritus & 22.7 \\
\hline & & ॥ & 27.3 & Onychomycosis, tinea Pedis & 18.2 \\
\hline & & RRD & 9.1 & Actinic keratosis & 9.1 \\
\hline Year & $\begin{array}{l}\text { Number of } \\
\text { diagnoses }\end{array}$ & The most common groups & $\begin{array}{l}\text { Percentage within group } \\
(\%)\end{array}$ & $\begin{array}{l}\text { The most common } \\
\text { diseases }\end{array}$ & $\begin{array}{l}\text { Percentage within group } \\
(\%)\end{array}$ \\
\hline \multirow{3}{*}{2014} & \multirow{3}{*}{87} & ॥ & 52.9 & Scabies & 27.6 \\
\hline & & $\mathrm{DE}$ & 19.5 & Contact dermatitis & 12.6 \\
\hline & & DSA & 15 & Acne Vulgaris & 9.2 \\
\hline \multirow{3}{*}{2015} & \multirow{3}{*}{115} & II & 52.2 & Scabies & 27 \\
\hline & & DSA & 16.5 & Seborrheic dermatitis & 6.1 \\
\hline & & $\mathrm{DE}$ & 16.5 & Acne vulgaris & 5.2 \\
\hline \multirow{3}{*}{2016} & \multirow{3}{*}{222} & ॥ & 39.2 & Acne vulgaris & 13.1 \\
\hline & & DSA & 24.3 & Scabies & 11.7 \\
\hline & & $\mathrm{DE}$ & 21.6 & Contact dermatitis & 9.9 \\
\hline \multirow{3}{*}{2017} & \multirow{3}{*}{430} & ॥ & 33.7 & Acne vulgaris & 13.9 \\
\hline & & DSA & 26 & Scabies & 11.4 \\
\hline & & $\mathrm{DE}$ & 23.5 & Contact dermatitis & 10.5 \\
\hline
\end{tabular}

II: Infection and infestations, DSA: Disorders of skin appendages, DE: Dermatitis and eczema, ODSST: Other disorders of the skin and subcutaneous tissue, RRD: Radiation-related disorders of the skin and subcutaneous tissue

Evaluation of our study based on years showed that prevalence of infectious dermatological diseases were significantly decreased, whereas, non-infectious diseases were significantly increased. These results are associated with the improved health, nutrition and accommodation conditions of asylum seekers in our country who are exposed to infectious dermatological diseases due to poor environmental and living conditions.

There were 316 pediatric patients in 0-18 age group (mean age: $9.3 \pm 5.8$ years). Most common disease groups were infections and infestations (43.1\%), dermatitis and eczema (23.9\%) and disorders of skin appendages (22.5\%), and most common diseases were scabies (16.6\%), acne vulgaris (10.7\%) and contact dermatitis (9\%). In our country, there are epidemiological studies on dermatological diseases observed in children. In their retrospective study including 1383 cases, Solak Tekin et al. ${ }^{14}$ reported that eczema group (25.9\%) was the most common, followed by infectious diseases (25.2\%) and unclassified dermatosis (15.4\%). Seçkin et al. ${ }^{15}$ conducted a study on 5,043 pediatric cases and reported most common disease groups as eczema (27\%), infectious diseases (22\%) and acne vulgaris (15.7\%). In our study, infectious dermatological disease rate in this group, which has the highest contact with local population, was significantly higher in comparison to the data around our country. Dermatitis and eczema prevalence was close to the reported data in our country. Again similar to the data of Inci et al. ${ }^{3}$, atopic dermatitis $(0.3 \%)$ prevalence was very low.

In our study, acne vulgaris was found to be the most common disease in $10-19$ and $19-30$ age groups (19.1\% and $23.3 \%$, respectively), being more significant in women. In two different studies conducted in our country, acne vulgaris (25.2\% and $30.6 \%$, respectively) was reported to be the most common disease in adolescent group ${ }^{14,15}$. Acne vulgaris prevalance in Syrian patients is similar to the data reported in our country. In our study, dermatitis and eczema was the second most common disease group in male patients, and third most common in all cases and female patients. In this group, contact dermatitis (9.6\%) was the most frequently diagnosed disease. There is no up-to-date literature about the prevalence of dermatological diseases in general population of our country. In a study covering five European countries, 15\% contact dermatitis prevalence was reported ${ }^{16}$. 
Among studies conducted with geriatric age groups in our country, Baş et al. ${ }^{17}$ studied 2,734 patients and reported that eczema, fungal skin diseases and pruritus were the most common diseases. In a study conducted by Özyurt et al. ${ }^{18}$ on this group, most frequently detected dermatological diseases were eczema (32.9\%), senile pruritus (14.6\%) and superficial fungal diseases (14.5\%). There were 16 cases over 60 years of age and the most common disease group was dermatitis and eczema (40.9\%) and most common disease was pruritus (22.7\%). Although data may not be objective due to few number of patients, it was determined that these cases admitted to the outpatient clinic due to the problems that are most frequent for this age group.

Stress and other psychological factors are known to cause many dermatological diseases or trigger the exacerbation of dermatoses ${ }^{19}$. Although it can be considered that psychogenic dermatological diseases can occur or existing skin diseases can exacerbate in Syrian asylum seekers due to poor living conditions, evaluation of disease prevalence showed that there was only one case with a primary psychocutaneous disease, lichen simplex chronicus. Among diseases with psychoneuroimmunological factors in their etiology, psoriasis had 2-4\% prevalence, alopecia areata $0.7-3.8 \%$, seborrheic dermatitis $10 \%$, vitiligo $0-2 \%$ and $1-8 \% 20-23$. As disease severity information was unavailable in our study, no interpretation can be provided on the presence of any exacerbation in the symptoms of existing diseases. However, prevalence of psoriasis, alopecia areata, vitiligo and seborrheic dermatitis were similar to the general population. This finding does not support the opinion that psychosomatic diseases occur in response to stress.

\section{Study Limitation}

The most important restrictions of this study are single-centered design and its retrospective. Also, the data is limited to those recorded in the automation system. The unknown dermatological problems seen as insignificant by the cases and insufficient disease severity data and background information prevent us from reaching more detailed epidemiological data.

\section{Conclusion}

Data we have obtained suggest that asylum seekers that were forced to come to Turkey are exposed to many skin diseases, especially infectious dermatological diseases. Although infectious dermatological disease prevalence decreased over the time they have been in our country, male and child cases that have the highest contact with the local people are still under risk. Improvement of preventive healthcare services, social support programs and resolution of communication problems can positively contribute to the lives of asylum seekers and as a result the local communities.

Our study is the first study about skin diseases in Syrian asylum seekers in Marmara region and can be instructive for the future studies. This study may contribute to the development of local or even national healthcare policies. Multi-center and prospective studies with wider populations can provide more insight and objective results.

\section{Ethics}

Ethics Committee Approval: The study was approved by the University of Health Sciences Turkey, Hamidiye Non-invasive Research Ethics Committee (approval number: 46418926, date: 30.11.2018).

Informed Consent: Due to the retrospective nature of this study, informed consent form was not obtained from the patients.
Peer-review: Externally peer-reviewed.

Financial Disclosure: The authors declared that this study received no financial support.

\section{References}

1. Pandır M, Efe I, Paksoy AF: A content analysis on the representation of Syrian asylum seekers in the Turkish press. Marmara Journal of Communication 2015;24:1-26.

2. Paksoy $A F$, Şentöregil $M$ : Syrian asylum seekers in the Turkish press: The analysis of the first 5 years (2011-2015). Journal of Selcuk Communication 2018;11:237-56.

3. Inci R, Ozturk P, Mülayim MK, et al: Dermatological face of Syrian civil war. Arch Turk Dermatol Venerology 2016;50:145-9.

4. Akıncı B, Nergiz A, Gedik E: An assesment on process of adaptation: Migration and social acceptance. The Journal of Migration Studies 2015:1:58-83.

5. Aygün O, Gökdemir Ö, Bulut Ü, Yaprak S, Güldal D: Evaluation of primary health care services which is provided to refugees within a Public Health Center. TJFM\&PC 2016;10:6-12.

6. van Berlaer $G$, Bohle Carbonell $F$, Manantsoa $S$, et al: A refugee camp in the centre of Europe: clinical characteristics of asylum seekers arriving in Brussels. BMJ Open 2016;6:e013963.

7. Refaat MM, Mohanna K: Syrian refugees in Lebanon: facts and solutions. Lancet 2013;382:763-4.

8. Sharara SL Kanj SS: War and infectious diseases: challenges of the Syrian civil war. PLoS Pathog 2014;10:e1004438.

9. Beldjebel I: Infectious diseases in refugees coming from Syria and Iraq to Lebanon. Int J Infect Dis 2014;21:6.

10. Wollina U, Gaber B, Mansour R, Langner D, Hansel G, Koch A: Dermatologic challenges of health care for displaced people. Lessons from a German emergency refugee camp. Our Dermatol Online 2016;7:136-8.

11. Öztürk R: Göç ve enfeksiyonlar. Sağlık Düşüncesi ve Tıp Kültürü Dergisi 2014:32:58-9.

12. Elsheik K, Eltaweel A: Epidemiology of cutaneous Leishmania sis cases in Syria 2011. Syrian Epidemiol Bull 2012;6:3-5.

13. Korkmaz S, Özgöztaşı O, Kayıran N: The assesment of cutaneous leishmaniasis patients admiting to Gaziantep University of Medicine Faculty Leishmaniasis Diagnosis and Treatment Center. Turkiye Parazitol Derg 2015;39:13-6.

14. Solak Tekin N, Sezer T, Altınyazar HC, Koca R, Çınar S: Prevalance of skin diseases in childhood in the region of Zonguldak: A Five-year retrospective analysis. Turkiye Klinikleri J Dermatol 2007;17:92-8.

15. Seçkin HY, Kalkan G, Baş Y: Prevalence of skin conditions among pediatric patients in the region of Tokat. Gaziosmanpaşa Üniversitesi Tıp Fakültesi Dergisi 2013;5:8-15.

16. Svensson A, Ofenloch RF, Bruze $M$, et al: Prevalence of skin disease in a population-based sample of adults from five European countries. $\mathrm{Br} J$ Dermatol 2018;178:1111-8.

17. Baş Y, Kalkan G, Seçkin HY, Takcı Z, Şahin Ş, Demir AK: Analysis of dermatologic problems in geriatric patients. Turk J Dermatol 2014;2:95-100.

18. Özyurt K, Avcı A, Çınar SL, Silay E: Geriatrik hastalarda dermatolojik sorunlar. Turk J Dermatol 2014;4:206-9.

19. Mercan S, Altunay iK: Psychodermatology: A collaborative subject of psychiatry and dermatology. Turkish Journal of Psychiatry 2006;17:305-13.

20. Stern RS, Nijsten T, Feldman SR, Margolis DJ, Rolstad T: Psoriasis is common, carries a substantial burden even when not extensive, and is associated with widespread treatment dissatisfaction. J Investig Dermatol Symp Proc 2004;9:136-9.

21. Oğuz O: Alopecia areata. Arch Turk Dermatol Venerology 2014;48:(Özel Sayı) 1:40-4

22. Naldi N: Seborrhoeic dermatitis. BMJ Clin Evid 2010:7.

23. Osinubi $\mathrm{O}$, Grainge MJ, Hong L, et al. The prevalence of psychological comorbidity in people with vitiligo: A systematic review and meta-analysis. Br J Dermatol 2018;178:863-78. 